Vol. 3, No. 2, Juli 2019, 75-85

Available Online at https://ejournal.warmadewa.ac.id/index.php/kulturistik DOI: dx.doi.org/10.22225/kulturistik.3.2.1203

\title{
KAJIAN LINGUISTIK HISTORIS KOMPARATIF PADA POLA PERUBAHAN BUNYI
}

\author{
Ida Ayu Iran Adhiti \\ Institut Keguruan dan Ilmu Pendidikan \\ dayuiran@gmail.com
}

\begin{abstract}
ABSTRAK
Bahasa-bahasa daerah di wilayah Nusa Tenggara Timur perlu diteliti, dikaji, dibina, dan dilestarikan. Kajian data terhadap fenomena kebahasaan dilakukan secara mendalam terutama bahasa-bahasa daerah yang hidup dan berkembang di Pulau Alor. Fenomena kebahasaan yang dikaji menyangkut tentang pola perubahan bunyi terhadap bahasa Kabola, bahasa Hamap, dan bahasa Klon di Pulau Alor. Keseluruhan pendataan terhadap ketiga bahasa dikaji dengan studi linguistik historis komparatif. Peneliti yang mengkaji bahasabahasa di Pulau Alor menggunakan pendekatan sinkronik, untuk mengetahui perkembangan bahasa pada satu kurun waktu. Teori yang digunakan untuk mengkaji tentang pola perubahan bunyi pada bahasa Kabola, bahasa Hamap, dan bahasa Klon di Pulau Alor adalah Blust (2013). Hock (1988), Crowley (1987), Chomsky (1968), Dyen (1978), Schane (1973), Bynon (1979), Antila (1972), Jeffers dan Lehiste (1979), dan Keraf (1996). Hasil penelitian diharapkan generasi muda sebagai penutur bahasa daerah menyadari dan memahami bahwa bahasa mereka merupakan moyang bahasa yang sama agar dibina, dikembangkan, dan dilestarikan sehingga mampu sebagai pendukung bahasa nasional.
\end{abstract}

Kata kunci: linguistik historis komparatif, pola perubahan bunyi, Kabola, Hamap, Klon

\begin{abstract}
[Title: Linguistic Study of Comparative Historis on Sound Change Patterns] The local languages in Nusa Tenggara Timur need to be observed, analysed, constructed, and conserved. Data research phenomena is done deeply approaching especially the local languages, which exist and develop in Alor Island. The observer analyses language phenomena on pattern of sound change in the languages of Kabola, Hamap, and Klon in Alor Island. The complete data of the three language are analysed by the study of comparative historic linguistic. The observation that analyses the languages in Alor Island use the synchronous approach, to know the language development in a period. The theory is used to analyse the pattern of sound change in the languages of Kabola, Hamap, and Klon in Alor Island is Blust (2013). Hock, (1988), Crowley (1987), Chomsky (1968), Dyen (1978), Schane (1973), Bynon (1979), Antila (1972), Jeffers and Lehiste (1979), and Keraf (1996). The result of observation is hoped that the young generation as local language speaker realize and understand that their languages are the same origin of languages so they are reconstructed, developed, and conserved so that they can support national language.
\end{abstract}

Keywords: comparative historic linguistic, sound change pattern, Kabola, Hamap, Klon 
Vol. 3, No. 2, Juli 2019, 76

Available Online at https://ejournal.warmadewa.ac.id/index.php/kulturistik

DOI: dx.doi.org/10.22225/kulturistik.3.2.1203

\section{PENDAHULUAN}

Setiap bahasa memiliki ciri tertentu yang terdapat pula dalam bahasabahasa lain. Seorang linguis diharapkan mampu menguasai secara reseptif satu atau lebih bahasa di samping bahasanya sendiri. Peneliti melakukan kajian bahasa selayaknya tidak serumpun dengan bahasa yang dikuasai oleh peneliti sendiri (Verhaar, 1984: 6). Bahasa dan budaya memiliki prinsip-prinsip tertentu terhadap kesemestaan bahasa. Hal tersebut menentukan konsep bahasa dalam aspek lain dari prilaku manusia. Istilah kekerabatan terkait dengan wilayah semantik pada konsep bahasa terhadap prilaku linguistik.

Perbandingan antara dua bahasa atau lebih dapat dikatakan sesuai usianya dengan timbulnya ilmu bahasa itu sendiri. Pemahaman tentang suatu bahasa sangat menarik perhatian untuk mengetahui sejauh mana terdapat kesamaan atau kemiripan antara aspek bahasa tersebut. Pendekatan tersebut dimulai dengan unsur-unsur kata, perlahan-lahan berkembang terus menuju perbandingan yang lebih kompleks. Pada prinsipnya linguistik historis komparatif pada bertugas mendeskripsikan tentang perkembangan sejarah bahasa dan kekerabatan bahasa yang ada di dunia (Keraf, 1990: 1).

Data dari suatu bahasa dipelajari dari dua periode atau lebih ynng diperbandingkan secara cermat untuk memperoleh kaidah-kaidah perubahan yang terjadi dalam bahasa itu. Unsur-unsur yang sama diperbandingkan berdasarkan kenyataan dalam periode yang sama dan perubahan-perubahan yang terjadi antara bebrapa periode. Cabang ilmu ini menekankan pada teknik dalam prasejarah bahasa. Data prasejarah dapat menjangkau kehidupan sejarah bahasanya dan dapat diketahui perkembangan serta pencabangan dalam bahasa-bahasa tertentu (Keraf, 1966: 22).

Linguistik bandingan memiliki tujuan dan manfaat: (1) mempersoalkan hubungan antar beberapa bahasa, untuk memperoleh perbandingan terhadap bahasa yang serumpun sehingga diperoleh kekerabatan bahasa tersebut;; (2) mengadakan rekonstruksi terhadap beberapa bahasa purba atau bahasa proto yang merupakan moyang bahasa yang diteliti; (3) beberapa bahasa dikelompokkan (subgrouping) terutama yang termasuk dalam satu rumpun bahasa, karena ada beberapa bahasa yang memperlihatkan keanggotaannya lebih dekat atau sama dibandingkan dengan beberapa bahasa atau kelompok bahasa lainnya.; serta (4) menemukan pusat-pusat penyebaran bahasa-bahasa proto (negeri asal: home land) dari bahasa-bahasa kerabat dan menetapkan gerak migrasi yang pernah terjadi pada jaman lampau (Keraf, 1966: 23 - 24).

Tugas utama linguistik historis komparatif adalah menetapkan data bahasa dan kekerabatan antar bahasa yang dikaji sehingga terkait erat dengan pengelompokan bahasa (Antilla, 1972: 20). Selanjutnya Hock dan Arlotto mengungkapkan bahwa dalam kajian linguistik komparatif dapat dibuktikan adanya unsur-unsur warisan dari bahasa asalnya atau bahasa proto (Arlloto, 1981: 10; Hock, 1988: 60) . Hubungan kekerabatan antarbahasa diperoleh dari bahasabahasa yang serumpun. menunjukkan bukti adanya keaslian, terwaris dari moyang yang sama (Antilla, 1972, p. 20; Dyen, 1988, p. 35; Keraf, 1966, p. 22).

Dengan demikian, bahasa-bahasa proto yang berkembang pada masa lalu berubah menjadi beberapa bahasa turunan disebabkan oleh tempat dan waktu. Bahasa-bahasa turunan yang berkembang, berbeda dengan bahasa asalnya terjadi secara turun-temurun. Fakta-fakta kebahasaan dalam wujud keteraturan dan kesepadanan yang ditemukan pada bahasa-bahasa kerabat menunjukkan bukti adanya 
Vol. 3, No. 2, Juli 2019, 77

Available Online at https://ejournal.warmadewa.ac.id/index.php/kulturistik DOI: dx.doi.org/10.22225/kulturistik.3.2.1203

keaslian bersama serta terwaris dari moyang yang sama. Pembuktian tentang kenyataan ini dapat dikaji pada bahasa-bahasa yang berkerabat, salah satunya adalah kajian tentang pola perubahan bunyi.

Menurut Chaer mengatakan bahwa tidak semua bunyi yang dihasilkan oleh alat ucap manusia termasuk bunyi bahasa. Bunyi bahasa adalah lambang bahasa yang dihasilkan oleh alat ucap manusia, tetapi tidak semua bunyi yang dihasilkan oleh alat ucap manusia termasuk bunyi bahasa (Chaer, 2014)

Adanya keteraturan bunyi bahasa serta kontradiksi dengan istilah arbitrer atau sesuka hati, karena tidak ada hubungan antara simbul (the symbols) dengan yang disimbulkannya (the symbolized). Setiap bunyi bahasa bersifat mana suka, tetapi bahasa adalah kekayaan sosial maka nanasuka dapat disetujui pemakaiannya oleh masyarakat penuturnya. Apabila terjadi kebiasaan (convensional), maka manasuka menjadi peraturan yang tetap dan merupakan suatu sistem. Dengan demikian dapat dikatakan bahwa bahasa bersifat manasuka yakni bahasa itu sosial konvensional serta bahasa itu arbitrer dan non arbitrer (Alwasilah, 1986: 76).

Hock mengungkapkan, bahwa unsur-unsur warisan yang terdapat pada bahasa proto atau bahasa asal pada prinsipnya membuktikan adanya merupakan hubungan kekerabatan antarbahasa serumpun yang dikaji dalam kajian historis komparatif. Beberapa perubahan bunyi dapat terjadi, seperti: peleburan (merger), perengkahan (split), penunggalan (monophonemization), penggugusan (diphonemization), dan peluluhan bunyi (phonemic loss) (Hock, 1988, p. 72).

Perubahan bunyi dapat terjadi seperti: peleburan, yakni penggabungan fonem atau lebih menjadi satu fonem; perengkahan, yakni satu fonem membelah menjadi dua fonem atau lebih; panunggalan, yakni perubahan gugus fonem menjadi sebuah fonem; penggugusan, yakni perubahan sebuah fonem menjadi dua fonem bergugus; serta peluluhan bunyi, yakni perubahan bunyi berupa hilangnya fonem baik pada posisi awal (aphaeresis), tengah (syncope), maupun akhir (apocope) serta pertukaran letak fonem (metathesis) (Budasi, 2007, p. 24; Keraf, 1966, pp. 82-83)

Perubahan linier merupakan perubahan sebuah fonem proto ke dalam bahasa sekarang dan tetap mempertahankan ciri-ciri fonetis fonem protonya. Peringkat kelemahan dan kekuatan vokal dideretkan dari lemah ke kuat seperti: $\mathrm{o}>\mathrm{e}>\mathrm{u}>\mathrm{a}>\mathrm{i}$. Perubahan dengan pelemahan fonem adalah perubahan fonem dari bunyi bahasa yang kuat menjadi lemah seperti: $b>p, p>f, f>h, x>h, b>w, v>w$, a $>$ a, d $>1$, s $>$ r, k>s,h. (Budasi, 2007, p. 25; Putra, 2007, pp. 331-333)

\section{METODE}

Pada kajian ini diberikan contoh tiga bahasa Alor yang tergolong berkerabat, yakni bahasa Kabola, bahasa Hamap, dan bahasa Klon di Pulau Alor, dikaji dengan analisis kualititatif. Metode perbandingan yang digunakan bersifat sinkomparatif, yakni menemukan ciri-ciri kesamaan dan keberbedaan antarbahasa kerabat yang hidup pada masa yang sama. Fenomena kebahasaan yang dikaji bersifat deskriptif, data yang dikumpulkan adalah data pada masa sekarang.

Data dianalisis dengan menggunakan metode deskriptif analitis, mendeskripsikan bahasa-bahasa yang dikaji dari 1.500 kosakata daftar Holle. Teknik lanjutannya adalah teknik hubung banding, baik hubung banding membedakan maupun menyamakan (Djajasudarma, 1993, p. 58; Sudaryanto, 1986b, pp. 13-30)

Penyajian hasil analisis menggunakan metode formal, yakni perumusan 
Vol. 3, No. 2, Juli 2019, 78

Available Online at https://ejournal.warmadewa.ac.id/index.php/kulturistik DOI: dx.doi.org/10.22225/kulturistik.3.2.1203

dengan tanda dan lambang-lambang. Tanda yang dimaksud seperti: tanda /..../ menunjukkan ejaan fonemis; tanda $(*)$ tanda bintang, menunjukkan proto; tanda panah $(\rightarrow)$ tanda arah perubahan; tanda kurung biasa (( )); kurung kurawal ( \{\}$)$; dan sebagainya (Sudaryanto, 1986: 45).

\section{PEMBAHASAN}

Peleburan (Merger) satu fonem

Peleburan bunyi merupakan penggabungan dua fonem atau lebih menjadi

1) PKbHpKl: *b; *1

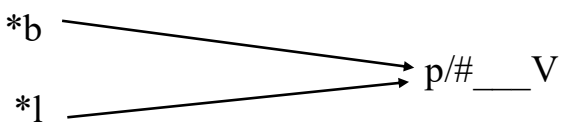

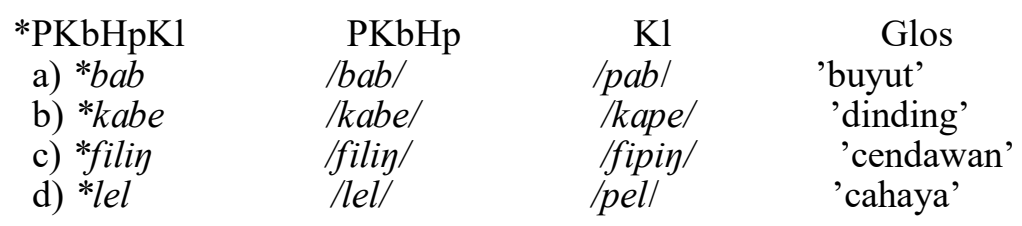

Data di atas menunjukkan terjadinya peleburan bunyi yakni fonem *b dan *1 menjadi /p/. Data a), b) menunjukkan fonem *b (bahasa KbHp) berubah menjadi /p/ (bahasa Kl), pada posisi awal kata. Fonem *b merupakan konsonan hambat-berubah menjadi fonem $/ \mathrm{p} /$ merupakan konsonan hambat-bilabial. Fonem*1 (bahasa $\mathrm{KbHp}$ ) merupakan konsonan sampingan-apikoalveolar berubah menjadi fonem $/ \mathrm{p} /$ merupakan konsonan hambat-bilabial. Dengan demikian peleburan tersebut sebagai bukti kuat bahwa KbHp merupakan satu kelompok yang terpisah dengan $\mathrm{Kl}$.

2) PKbHpKl: *n; *k

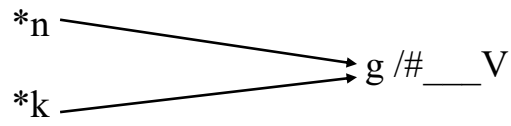

$\begin{array}{lccc}\text { *PKbHpK1 } & \mathrm{PKbHp} & \mathrm{Kl} & \text { Glos } \\ \text { a) *ney mari } & / \text { ney mari/ } & / \text { gen mari/ } & \text { 'air mata' } \\ \text { b) *katan } & / \text { katay/ } & \text { /gatay/ } & \text { 'angkat' }\end{array}$

Data di atas menunjukkan terjadinya peleburan bunyi yakni fonem *n dan *k menjadi /g/. Data a), b) menunjukkan fonem *n (bahasa KbHp) berubah menjadi /g/ (bahasa Kl), pada posisi awal kata. Fonem *n merupakan konsonan sengau-lamino-alveolar-menjadi /g/ yang merupakan konsonan hambat-dorsovelar. Fonem*k (bahasa $\mathrm{KbHp}$ ) merupakan konsonan hambat-dorsovelar berubah menjadi fonem $/ \mathrm{g} /$ merupakan konsonan hambat-doesovelar pula. Dengan demikian peleburan tersebut sebagai bukti kuat bahwa $\mathrm{KbHp}$ merupakan satu kelompok yang terpisah dengan $\mathrm{Kl}$.

3) PKbHpKl: *p; *t

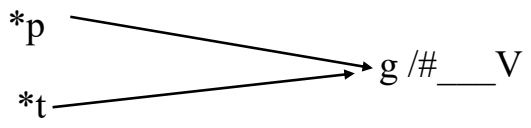

KULTURISTIK: Jurnal Bahasa dan Budaya E-ISSN: 2580-4456 P-ISSN: 2580-9334 Copyright $(\mathbf{C} 2019$ 
Vol. 3, No. 2, Juli 2019, 79

Available Online at https://ejournal.warmadewa.ac.id/index.php/kulturistik DOI: dx.doi.org/10.22225/kulturistik.3.2.1203

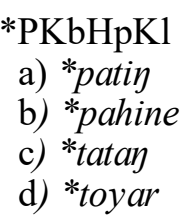

*PKbHpKl

a) *patin

b) *pahine

d) *toyar

PKbHp
/patiy/
/pahine/
/tatay/
/toyar/

$\mathrm{PKbHp}$

/pahinel

/toyar/

K1
'gatiy/
'gahine/
'gatay/
goyar/

Glos

'telapak kaki'

'bisul'

'bertanya'

'tante'

Data di atas menunjukkan terjadinya peleburan bunyi yakni fonem *p dan *t menjadi /g/. Data a), b), c), dan, d) menunjukkan fonem *p (bahasa KbHp) berubah menjadi /g/ (bahasa Kl), pada posisi awal kata. Fonem *p merupakan konsonan hambat-bilabial-menjadi /g/ yang merupakan konsonan hambatdorsovelar. .Fonem*t (bahasa $\mathrm{KbHp}$ ) merupakan konsonan sampinganlaminoalveolar berubah menjadi fonem /g/ merupakan konsonan hambatdorsovelar. Dengan demikian peleburan tersebut sebagai bukti kuat bahwa KbHp merupakan satu kelompok yang terpisah dengan $\mathrm{Kl}$.

4) PKbHpKl: *f; *h

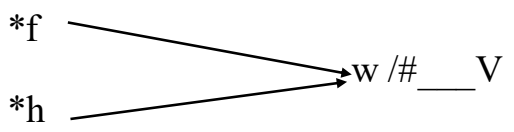

$\begin{array}{llll}\text { *PKbHpKl } & \text { PKbHp } & \text { Kl } & \text { Glos } \\ \text { a) *fui tit } & \text { /fui tit/ } & \text { /wui tit/ } & \text { 'darah merah' } \\ \text { b) *fui afel } & \text { /fui afel/ } & \text { /wui afel/ } & \text { 'darah putih' } \\ \text { c) *hedoy } & \text { /hedoy/ } & \text { /wedoy/ } & \text { 'kini' } \\ \text { d) *ehey } & \text { lehey/ } & \text { /ewey/ } & \text { 'lima' }\end{array}$

Data di atas menunjukkan terjadinya peleburan bunyi yakni fonem *f dan *h menjadi /w/. Data a), b), c), dan, d) menunjukkan fonem *f (bahasa KbHp) berubah menjadi /w/ (bahasa Kl), pada posisi awal kata. Fonem *f merupakan konsonan geseran-labiodental-menjadi /g/ yang merupakan konsonan hambatdorsovelar. .Fonem*h (bahasa KbHp) merupakan konsonan geseran-faringal berubah menjadi fonem /g/ merupakan konsonan hambat-doesovelar. Dengan demikian peleburan tersebut sebagai bukti kuat bahwa KbHp merupakan satu kelompok yang terpisah dengan $\mathrm{Kl}$.

\section{Perengkahan (Split)}

Perubahan bunyi bentuk perengkahan (split) merupakan gejala perubahan fonem membelah menjadi dua fonem atau lebih.
1) $\mathrm{PKbHpKl--*k}$<smiles>[Tl]</smiles><smiles>C[14C](C)C</smiles>
$\mathrm{PKbHpKl}$
a) *kemini
b) *keka
$\mathrm{PKbHp}$
/kemini/
lkekal
$\mathrm{K} 1$
/gemini/ lhekal
Glos
'membunuh'
'ayakan'

Data a) dan b) di atas menunjukkan, bahwa terjadi perengkahan bunyi yakni fonem *k menjadi /g/ dan /h/. Data a) dan b), menunjukkan fonem *k (bahasa $\mathrm{KbHp}$ ) berubah menjadi /g/ dan /h/ (bahasa Kl), pada posisi awal kata. Fonem *k 
Vol. 3, No. 2, Juli 2019, 80

Available Online at https://ejournal.warmadewa.ac.id/index.php/kulturistik DOI: dx.doi.org/10.22225/kulturistik.3.2.1203

merupakan konsonan hambat-dorsovelar berubah menjadi fonem /g/ merupakan konsonan hambat-dorsovelar, fonem $/ \mathrm{h} / \mathrm{m}$ merupakan konsonan geseran-laringal. Dengan demikian perengkahan tersebut sebagai bukti kuat bahwa KbHp merupakan satu kelompok yang terpisah dengan $\mathrm{Kl}$.

2) PKbHpKl: *f<smiles>[AlH][Y10]([AlH2])=[V]</smiles>

\begin{tabular}{|c|c|c|c|}
\hline $\begin{array}{l}\text { PKbHpKl } \\
\text { a) *fal } \\
\text { b) * fail } \\
\text { c) * fay }\end{array}$ & $\begin{array}{l}\mathrm{PKbHp} \\
\text { /fal/ } \\
\text { /fail/ } \\
\text { /fay/ }\end{array}$ & $\begin{array}{l}\mathrm{Kl} \\
\text { /kal/ } \\
\text { /kail/ } \\
\text { /tay/ }\end{array}$ & $\begin{array}{l}\text { Glos } \\
\text { 'bekal' } \\
\text { 'berdagang' } \\
\text { 'berlayar' }\end{array}$ \\
\hline
\end{tabular}

Data a), b), dan c) di atas menunjukkan, bahwa terjadi perengkahan bunyi yakni fonem $*_{\mathrm{f}}$ menjadi $/ \mathrm{k} /$ dan $/ \mathrm{t} /$. Data $\left.\mathrm{a}\right)$, b), dan c) menunjukkan fonem $*_{\mathrm{f}}$ (bahasa $\mathrm{KbHp}$ ) berubah menjadi /k/ dan /t/ (bahasa Kl), pada posisi awal kata. Fonem *f merupakan konsonan geseran-labiodental berubah menjadi fonem $/ \mathrm{k} /$ merupakan konsonan hambat-dorsovelar, fonem /t/ merupakan konsonan hambatlaminoalveolar. Dengan demikian perengkahan tersebut sebagai bukti kuat bahwa $\mathrm{KbHp}$ merupakan satu kelompok yang terpisah dengan Kl.

\section{Panunggalan (Monophonemization)}

Perubahan bunyi bentuk panunggalan adalah perubahan bunyi dari beberapa gugus fonem menjadi sebuah fonem.

1) PKbHpKl: *ai; *ua $\rightarrow e$

$$
\begin{aligned}
& *_{\text {ai }} \\
& *_{\text {ua }}
\end{aligned}
$$<smiles>[AlH2][CH][AlH2]</smiles>
$\mathrm{PKbHpKl}$
a) *waike
b) *taipah
c) *dual
d) *kua
e) *mua

PKbHp
/waikel
/taipah/
/dual/
/kual
/mual

$\mathrm{K} 1$

/wekel

taipel

/del/

/kel

Imel

$$
\begin{aligned}
& \text { Glos } \\
& \text { 'tanah' } \\
& \text { 'tebal' } \\
& \text { 'menghisap' } \\
& \text { 'kokoh' } \\
& \text { 'mengingat' }
\end{aligned}
$$

Data a), b), c), d), dan e) di atas menunjukkan terjadi panunggalan (monophonemization) yakni perubahan gugus fonem menjadi sebuah fonem. $\mathrm{Pa}$ nunggalan yang terjadi antara *ai dan *ua (bahasa $\mathrm{KbHp}$ ) menjadi /e/ (bahasa $\mathrm{Kl}$ ) pada posisi tengah kata. Fonem vokal rendah diikuti oleh vokal tinggi depan serta vokal belakang diikiuti oleh vokal depan, bawah menjadi vokal depan dan tengah pada proses panunggalan. Dengan demikian perengkahan tersebut sebagai bukti kuat bahwa KbHp merupakan satu kelompok yang terpisah dengan Kl.
2) PKbHpKl: *au; *ua $\rightarrow$ o

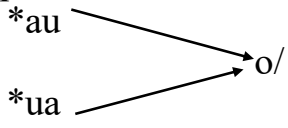

$$
\mathrm{K} \_\mathrm{V} ;-\#-
$$$$
\mathrm{K}-\mathrm{K} ;-\#-
$$ 
Vol. 3, No. 2, Juli 2019, 81

Available Online at https://ejournal.warmadewa.ac.id/index.php/kulturistik DOI: dx.doi.org/10.22225/kulturistik.3.2.1203

\section{$\mathrm{PKbHpKl}$}

a) *kaui

b) *anau

c) *atuar

d) *buan

$\mathrm{PKbHp}$
/kaui/
lanau/
latuar/
/buay/

$\mathrm{K} 1$
/koi/
lano/
lator/
/boy/

Glos

'rumput'

'siapa'

'arus'

'berjaga'

Data a), b), c), dan d) di atas menunjukkan terjadi panunggalan (monophonemization) yakni perubahan gugus fonem menjadi sebuah fonem. $\mathrm{Pa}$ nunggalan yang terjadi antara *au dan *ua (bahasa $\mathrm{KbHp}$ ) menjadi /o/ (bahasa Kl) pada posisi tengah kata. Fonem vokal rendah diikuti oleh vokal tinggi belakang serta vokal tinggi belakang diikuti oleh depan bawah menjadi vokal madya belakang pada proses panunggalan. Dengan demikian perengkahan tersebut sebagai bukti kuat bahwa KbHp merupakan satu kelompok yang terpisah dengan $\mathrm{Kl}$.

\section{Penggugusan (Diphonemization)}

Penggugusan merupakan perubahan bunyi pada sebuah fonem menjadi dua fonem yang bergugus. Penggugusan dari monofonem menjadi difonemisasi atau perengkahan merupakan istilah pada linguistik historis komparatif.

1) PKbHpKl: $* \mathrm{e} \rightarrow$ ai, ia<smiles>[13CH3][13CH3]</smiles><smiles>[V]</smiles>
\#

$\begin{array}{llll}\text { PKbHpKl } & \text { PKbHp } & \mathrm{Kl} & \text { Glos } \\ \text { a) *sanele } & \text { /sanele/ } & \text { /sanelai/ } & \text { 'daun jendela' } \\ \text { b) *udume } & \text { /udume } & \text { /udumai/ } & \text { 'harapan' } \\ \text { c) *de } & \text { /de/ } & \text { /dia/ } & \text { 'dilahirkan' } \\ \text { d) *tibe } & \text { Itibel } & \text { Itibial } & \text { 'gendrang' }\end{array}$

Data 1) a), b), c), dan, d) di atas menunjukkan terjadi penggugusan yakni perubahan satu fonem menjadi dua fonem. Penggugusan yang terjadi antara fonem *e (bahasa $\mathrm{KbHp}$ ) menjadi /ai/ dan /ia/ (bahasa Kl) pada posisi akhir kata. Fonem depan tengah berupah menjadi depan belakang diikuti oleh depan tinggi serta diikuti oleh depan bawah pada penggugusan. Dengan demikian perengkahan tersebut sebagai bukti kuat bahwa $\mathrm{KbHp}$ merupakan satu kelompok yang terpisah dengan $\mathrm{Kl}$.
2) PKbHpKl: ${ }_{0} \rightarrow$ au, ua

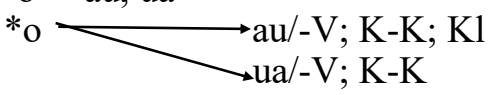

$\mathrm{PKbHpKl}$

a) *sarano

b) *kabolay

c) *doke

d) *no'so

e) *sabob
$\mathrm{PKbHp}$

/saranau/

/kabolay/

ldokel

Ino'so/

/sabob/
K1

/saranaul

|kabolauy/

Idaukel

Ino'saul

/sabuab/
Glos

'berdamai'

'bundar'

'cungkil'

'dokter'

'berkeluh kesah'

Data 1) a), b), c), d), dan e) di atas menunjukkan terjadi penggugusan yak- 
Vol. 3, No. 2, Juli 2019, 82

Available Online at https://ejournal.warmadewa.ac.id/index.php/kulturistik DOI: dx.doi.org/10.22225/kulturistik.3.2.1203

ni perubahan satu fonem menjadi dua fonem. Fonem /o/, fonem vokal belakangtengah berubah menjadi /au/ depan diikuti oleh fonem vokal rendah serta /ua/ fonem vokal belakang diikuti oleh fonem depan-rendah berubah menjadi /o/ fonem vokal belakang- madya. Penggugusan yang terjadi antara fonem $*_{0}$ (bahasa KbHp) menjadi /au/ dan /ua/ (bahasa Kl) pada posisi akhir kata. Dengan demikian perengkahan tersebut sebagai bukti kuat bahwa KbHp merupakan satu kelompok yang terpisah dengan $\mathrm{Kl}$.

\section{Peluluhan Fonem (Phonemic Loss)}

Peluluhan bunyi merupakan perubahan bunyi berupa hilangnya fonem baik pada posisi awal (apharesis), posisi tengah (syncope), dan posisi akhir (apacope).

1) Penghilangan fonem pada posisi awal kata (apharesis)

$* \mathrm{a}, * \mathrm{e}, * \mathrm{~d} \rightarrow \varnothing / \#$

\begin{tabular}{|c|c|c|c|}
\hline $\begin{array}{l}\text { PKbHpKl } \\
\text { a) *afail } \\
\text { b) *ewehey } \\
\text { c) *dafay } \\
\text { d) *aduy }\end{array}$ & $\begin{array}{l}\text { PKbHp } \\
\text { /afail/ } \\
\text { /ewehey/ } \\
\text { /dafay// } \\
\text { /aduy/ }\end{array}$ & $\begin{array}{l}\mathrm{K} 1 \\
\text { /fail/ } \\
\text { /wehey/ } \\
\text { lafay// } \\
\text { /duy/ }\end{array}$ & $\begin{array}{l}\text { Glos } \\
\text { 'nyala api' } \\
\text { 'gigi' } \\
\text { 'obat' } \\
\text { 'pipi' }\end{array}$ \\
\hline
\end{tabular}

Data a), b), c), dan d) di atas menunjukkan, bahwa terjadi penghilangan fonem pada awal kata. Fonem yang hilang pada data tersebut adalah fonem *a, $* \mathrm{e}, * \mathrm{~d}$.

2) Penghilangan fonem pada posisi tengah kata (syncope)

$$
* \mathrm{a},{ }^{*} \mathrm{~b},{ }_{\mathrm{w}}, * \mathrm{l} \rightarrow \varnothing / \mathrm{K}-\mathrm{K}
$$

\section{$\mathrm{PKbHpKl}$}

a) *amaebeh

b)*alabalin

c)*tuwuni

d)*lili

e)*palor

$\begin{array}{ll}\text { PKbHp } & \mathrm{K} 1 \\ \text { /amaebeh/ } & \text { /amebeh/ } \\ \text { lalabalig/ } & \text { /ala'aliy/ } \\ \text { /tuwuni/ } & \text { /tu'uni/ } \\ \text { /lili/ } & \text { /li'i/ } \\ \text { /palor/ } & \text { /pa'or/ }\end{array}$

Glos

'pandai besi'

'tangkai padi'

'sembunyi'

'terbang'

'peluru'

Data a), b), c), d), dan e) di atas menunjukkan terjadi penghilangan fonem pada tengah kata. Fonem yang hilang pada data tersebut adalah fonem *b dan *1.

3) Penghilangan fonem pada posisi akhir kata (apacope)

$$
*_{\mathrm{u}}, *_{\mathrm{i}}, *_{\mathrm{r}},{ }^{*} \mathrm{n} \rightarrow \varnothing /
$$
\#

$\begin{array}{llll}\text { PKbHpKl } & \text { PKbHp } & \text { Kl } & \text { Glos } \\ \text { a) *kupuhu } & \text { *kupuhu } & \text { /kupuh/ } & \text { 'sempit' } \\ \text { b) *minu } & *_{\text {minu }} & \text { /min/ } & \text { 'pertama kali' } \\ \text { c) *niwi } & *_{\text {niwi }} & \text { /niw/ } & \text { 'ibu' } \\ \text { d) *nar } & \text { *nar }_{\text {nar }} & \text { /nal } & \text { 'saya' } \\ \text { e) *afen } & \text { *afen } & \text { /afel } & \text { 'putus tali' }\end{array}$

Data a), b), c), d), dan e) di atas menunjukkan terjadi penghilangan fonem pada akhir kata. Fonem yang hilang pada data tersebut adalah fonem $* u, *_{i},{ }^{*}$, dan $*$ n Data tersebut menunjukkan adanya penghilangan fonem vokal pada posisi 
akhir kata (apacope).

\section{Penambahan Fonem (Addtion)}

Penambahan fonem (Addition) $\mathrm{PKbHpKl}$ ditemukan pada posisi awal (prothesis), posisi tengah (epentesis), dan posisi akhir (paragoge) pada protobahasa Kabola, Hamap, dan Klon ( $\mathrm{PKbHpKl}$ ) terhadap protobahasa Kabola (PHp) dan bahasa Klon.

1) Penambahan fonem pada posisi awal kata (protesis)

PKbHpKl
a) *tale
b) *dapu
c) *laana
d) *bey
e)*umuin

$$
\begin{aligned}
& \text { PKbHp } \\
& \text { *tale } \\
& \text { *dapu } \\
& \text { *laana } \\
& \text { *bey } \\
& \text { *umuin }
\end{aligned}
$$

$\begin{array}{ll}\text { K1 } & \text { Glos } \\ \text { la'tale/ } & \text { 'di atas', } \\ \text { ladapu/ } & \text { 'memasak' } \\ \text { la'laana/ } & \text { 'hitam' } \\ \text { le'bey/ } & \text { 'lain' } \\ \text { /gumuin/ } & \text { 'sepi' }\end{array}$

Data a), b), c), d), dan e) di atas menunjukkan adanya penambahan fonem / a/, /e/, dan /g/pada posisi awal kata. Fonem /a/, /e/, dan /g/ dari PKbHpK1 tetap bertahan pada $\mathrm{PKbHp}$, tetapi terdapat penambahan fonem pada Kl. Dengan demikian PKbHp merupakan satu sub kelompok sedangkan Kl merupakan satu kelompok tersendiri.

2) Penambahan fonem pada posisi tengah kata (epenthesis)

$\begin{array}{lccc}\text { PKbHpK1 } & \text { PKbHp } & \text { Kl } & \text { Glos } \\ \text { a) *bo'oi } & \text { *bo'oi } & \text { /boo'oi/ } & \text { 'kuning' } \\ \text { b) *kein } & \text { *kein } & \text { /keein/ } & \text { 'kecil' } \\ \text { c) *muriy } & \text { *murin } & \text { /muuriy/ } & \text { 'menanam' } \\ \text { d) *koini } & \text { *koini } & \text { /kobini/ } & \text { 'memukul' } \\ \text { e) *do'hel } & \text { *do'hel } & \text { /dolhel/ } & \text { 'melompat' }\end{array}$

Data a), b), c), d), dan e) di atas menunjukkan adanya penambahan fonem

\begin{tabular}{|c|c|c|c|}
\hline $\begin{array}{l}\text { PKbHpK1 } \\
\text { a)*ipin } \\
\text { b)*muam } \\
\text { c)*medele } \\
\text { d)*mu } \\
\text { e)*te }\end{array}$ & $\begin{array}{l}\text { PKbHp } \\
\text { *ipin } \\
\quad \text { *muam } \\
\text { *medele } \\
\text { *mu } \\
\text { *te }\end{array}$ & $\begin{array}{l}\text { K1 } \\
\text { /ipinal } \\
\text { /muamel } \\
\text { /medeleh/ } \\
\text { /muy/ } \\
\text { /tek/ }\end{array}$ & $\begin{array}{l}\text { Glos } \\
\text { 'minyak' } \\
\text { 'mengingat' } \\
\text { 'kilat' } \\
\text { 'jatuh' } \\
\text { 'menikam' }\end{array}$ \\
\hline
\end{tabular}
pada posisi tengah kata. Fonem yang muncul pada data tersebut adalah fonem / $\mathrm{o} /$, /e/, /u/, /b/, dan /1/ dari PKbHpKl tetap bertahan pada PKbHp, tetapi terdapat penambahan fonem di tengah kata pada Kl. Dengan demikian PKbHp merupakan satu sub kelompok sedangkan Kl merupakan satu kelompok tersendiri.

3) Penambahan fonem pada posisi akhir kata (paragoge)

Data di atas menunjukkan adanya penambahan fonem pada posisi akhir kata. Fonem yang muncul pada data tersebut adalah fonem /a/ dan /e/. Fonem / $\mathrm{a} /, / \mathrm{e} /, / \mathrm{h} / . / \mathrm{y} /$, dan $/ \mathrm{k} /$ dari $\mathrm{PKbHpKl}$ tetap bertahan pada PKbHp, tetapi terdapat penambahan fonem di akhir kata pada Kl. Dengan demikian PKbHp merupakan satu sub kelompok sedangkan $\mathrm{Kl}$ merupakan satu kelompok tersendiri. 
Vol. 3, No. 2, Juli 2019, 84

Available Online at https://ejournal.warmadewa.ac.id/index.php/kulturistik DOI: dx.doi.org/10.22225/kulturistik.3.2.1203

\section{Pertukaran Letak Fonem (Metathesis)}

Pertukaran letak fonem (Metathesis) pada bahasa Kabola, bahasa Hamap, dan bahasa Klon dapat disajikan pada data berikut.

$\begin{array}{llll}\text { PKbHpK1 } & \text { PKbHp } & \text { K1 } & \text { Glos } \\ \text { a)*toromi } & \text { *toromi } & \text { /mitoro/ } & \text { 'di mana' } \\ \text { b)*pebehe } & \text { *pebehe } & \text { /hebepel } & \text { 'daun' } \\ \text { c)*dopomi } & \text { *dopomi } & \text { /midopo/ } & \text { 'di' } \\ \text { d)*tanhiri } & \text { *tanhiri } & \text { /hiritay/ } & \text { 'garam' } \\ \text { e)*komkaha } & \text { *komkaha } & \text { /hakahom/ } & \text { 'hati' } \\ \text { f)*kedunu } & \text { *kedunu } & \text { /dukenu/ } & \text { 'melihat' } \\ \text { g)*tawoi } & \text { *tawoi } & \text { /itawo/ } & \text { 'mengalir' } \\ \text { h)*tuwu } & \text { *tuwu } & \text { /wutu/ } & \text { 'menggaruk' } \\ \text { i)*tolopo } & \text { *tolopo } & \text { /lopoto/ } & \text { 'tulang' } \\ \text { j)*toroso } & \text { *toroso } & \text { /sotorul } & \text { 'mana' } \\ \text { k)*derefan } & \text { *derefay } & \text { /farderel } & \text { 'manis' }\end{array}$

Data a), b), c), d), e), f), g), h), i), j), dan k) di atas menunjukkan adanya pertukaran letak fonem pada kata. Pertukaran letak tersebut adalah suku kata mi, he, tan, hom, ke, wo, tu, to, so, dan fan. Suku kata PKbHpKl tetap bertahan pada PKbHp, tetapi terdapat penambahan fonem di akhir kata pada Kl. Dengan demikian PKbHp merupakan satu sub kelompok sedangkan Kl merupakan satu kelompok tersendiri.

\section{SIMPULAN}

Linguistik Historis Komparatif merupakan cabang ilmu bahasa yang mempersoalkan bahasa dalam bidang waktu serta perubahan-perubahan unsur bahasa, terjadi pada bidang waktu tersebut. Unsur-unsur yang sama diperbandingkan berdasarkan kenyataan dalam periode yang sama dan perubahan-perubahan yang terjadi dalam beberapa periode.

Bahasa-bahasa proto yang berkembang pada masa lalu berubah menjadi beberapa bahasa turunan disebabkan oleh tempat dan waktu. Bahasa-bahasa turunan yang berkembang, berbeda dengan bahasa asalnya terjadi secara turuntemurun. Fakta-fakta kebahasaan dalam wujud keteraturan dan kesepadanan yang ditemukan pada bahasa-bahasa kerabat menunjukkan bukti adanya keaslian bersama serta terwaris dari moyang yang sama. Pembuktian tentang kenyataan ini dapat dikaji pada bahasa-bahasa yang berkerabat, salah satunya adalah kajian tentang pola perubahan bunyi.

Beberapa perubahan bunyi dapat terjadi, seperti: peleburan (merger), perengkahan (split), penunggalan (monophonemization), penggugusan (diphonemization), peluluhan bunyi (phonemic loss), penambahan fonem (addition), dan pertukaran letak fonem (metathesis). Peluluhan bunyi (phonemic loss), terdapat pada posisi awal (aphaeresis), tengah (syncope), maupun akhir (apocope). Selanjutnya penambahan fonem (addition), terdapat pada posisi awal (protesis), tengah (epenthesis), dan akhir (paragoge).

\section{DAFTAR PUSTAKA}

Alwasilah, C. (1986). Linguistik suatu pengantar. Bandung: Angkasa.

Antilla, R. (1972). An Introduction to Historical and Comparative Linguistics.

New York: Macmillan Press LTD. 


\section{Sulliturisistillk \\ KULTURISTIK JURNAL BAHASA \& BUDAYA}

Vol. 3, No. 2, Juli 2019, 85

Available Online at https://ejournal.warmadewa.ac.id/index.php/kulturistik DOI: dx.doi.org/10.22225/kulturistik.3.2.1203

Arlloto, A. (1981). Introduction to Historical Linguistics. Boston: Houghton Mifflin.

Budasi, I. G. (2007). Kekerabatan bahasa-bahasa di Sumba (suatu kajian linguistik historis komparatif). Universitas Gadjah Mada.

Chaer, A. (2014). Linguistik Umum. Jakarta: Rineka Cipta.

Djajasudarma, T. F. (1993). Metode linguistik: ancangan metode penelitian dan kajian. Bandung: Eresco.

Dyen, I. (1988). Linguistic Subgrouping and Lexicostatistik. The Hague Paris: Mouton.

Hock, H. H. (1988). Principles of Historical Linguistics. Berlin, New York, and Amsterdam: Mouton de Gryter.

Keraf, G. (1966). Linguistik Bandingan Historis. Jakarta: PT Gramedia Pustaka Utama.

Keraf, G. (1990). Linguistik bandingan tipologis. Jakarta: PT Gramedia.

Putra, A. A. P. (2007). Segmentasi Dialektal Bahasa Sumba di Pulau Sumba: Suatu Kajian Dialektologi. Universitas Udayana, Denpasar.

Sudaryanto. (1986a). Metode linguistik. Yogyakarta: Gadjah Mada University Press.

Sudaryanto. (1986b). Metode Linguistik. Yogyakarta: Gadjah Mada University Press.

Verhaar, J. W. . (1984). Pengantar linguistik. Yogyakarta: Gadjah Mada University Press. 